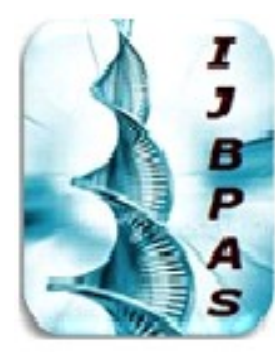

International Journal of Biology, Pharmacy and Allied Sciences (IJBPAS) 'A Bridge Betusen Caboratory and QRando' Www.iibpas,com

\title{
GC-MS ANALYSIS OF Caesalpinia bonducella
}

\section{P. EZHILARASAN ${ }^{1}$, S. SIVAKRISHNAN ${ }^{*}$, S.VIGIL ANBIAH ${ }^{2}$}

1: M.Pharm (Pharmacology), Department of Pharmacy, FEAT, Annamalai University

1*: Assistant Professor, Department of Pharmacy, FEAT, Annamalai University

2: Associate Professor and Head i/c, Central Animal House, Rajah Muthiah Medical College,

Annamalai University, AnnamalaiNagar-608002

*Corresponding Author: E Mail: sivacdm82@gmail.com

Received 22 ${ }^{\text {nd }}$ July 2019; Revised $7^{\text {th }}$ Oct. 2019; Accepted $7^{\text {th }}$ Jan. 2020; Available online $1^{\text {st }}$ June 2020

https://doi.org/10.31032/IJBPAS/2020/9.6.5075

\section{ABSTRACT}

Use of plants as a source of medicine has been inherited and is an important component of the health care system. Plants used for traditional medicine contain a wide range of substances that can be used to treat chronic as well as infectious diseases. Caesalpinia bonducella is an important medicinal plant for its traditional uses against different types of diseases. In the last few years, gas chromatography mass spectrometry (GC-MS) has become firmly established as a key technological platform for secondary metabolite profiling in both plant and non-plant species. This purpose of this study was to evaluate the GC-MS analysis of ethanolic extract of leaves of Caesalpinia bonducella.The leaves of Caesalpinia bonducella were collected from puthupalayam village, Villupuram District, Tamil Nadu, India. The extract was prepared from ethanol by hot continuous percolation method in soxhlet apparatus for 24 hours and evaluate the phytochemical activity of ethanolic extract of seeds of Caesalpinia bonducella and identification of active biochemical constituents using Perkin-Elmer Gas Chromatography-Mass Spectroscopy. The GC-MS analysis of ethanolic extract of seeds of Caesalpinia bonducella showed 17 bioactive compounds, the highest compound was named as 2,3-Di-OMethyl-D-Xylopyranose (31.842\%) and lowest was named as 2,4,4-Trimethyl-3- 
Hydroxymethyl-5A-(3-Methyl-But-2-Enyl)-Cyclohexene $(0.817 \%)$. In the present study, we concluded that the GC-MS analysis of the ethanolic extract of leaves of Caesalpinia bonducella shows various bioactive constituentsand it will be helpful to treat various disorders.

\section{Keywords: Medicinal Plants, GC-MS, Caesalpinia bonducella, Phytol, Ethanol, Leaves INTRODUCTION}

These medicinal plants are used to treatment for variety of diseases without any serious side effects. Plants are used medicinally in different countries, and they are the source of many potent and powerful drugs. Plants have been an important source of medicine with qualities for thousands of years. Mainly on traditional remedies such as herbs for their history, they have been used as popular folk medicines. Caesalpinia bonducella L. (Family: Fabaceae) is an important medicinal plant, which is widely distributed in the tropical and subtropical regions of Asia and the Caribbean.[1] In Bangladesh, this plant is abundant in forests and village thickets of Dhaka, Chittagong, Khulna, Tangail, and North Bengal. A large straggling, very thorny shrub, branches armed with hooks and straight hard yellow prickles; leaves bipinnate, large, stipules, foliaceous, pinnae 7 pairs, leaflets 3-8 pairs with 1-2 small recurved prickles between them on the underside; flowers yellow, in dense long peduncled supra-axillary racemes at the top; fruits inflated pods, covered with wiry prickles, seeds 1-2 per pod, oblong or globulat, hard, grey with a smooth shiny surface. The plant is known as Nata in Bengali and fever nut or nicker nut in English. Different parts of the plant have extensive uses in folk medicines for the treatment of a variety of diseases. [2, 3] Seeds contain stearic, palmitic, octadeca-4, octadeca-2, ligoceric, linolenic and oleic acids. They also contain bonducellin, arginine, citrulline and aspartic acid. The whole plant of Caesalpinia bonducella are used as a medicine. The leaves and the juice or paste is used to relieving smallpox, elephantiasis, liver diseases and for eliminating bad odour in perspiration. It is also used for reducing toothache. Bonducella has febrifuge, antiperiodic, anthelmitic and tonic properties. Pods are roasted and the powder is used as a substitute for quinine. The root bark has been used for relieving intestinal worms, fevers, tumors, cough, amenorrhea and to remove placenta after childbirth. The flower tastes bitter and induce warming effect on the body. It improves the balance of vata and kapha [4] and the ash is useful in ascites. Fruits of Caesalpinia 
bonducella used for treating piles, haemorrhoids, [5] wounds [6], leucorrhoea and urinary disorders. It also produces heat in the body, shows astringent activity on bowels and is known as an aphrodisiac. Boiled leaves can be used for gargling to relieve sore throat. The seeds have astringent properties and are being used to relieve inflammation, contagious disease, skin diseases [7], hydrocele, colic and leprosy. Seed sprouts are useful in relieving tumours. Leaves and seeds after roasting in castor oil can be applied to reduce piles, inflammatory swellings orchitis and hydrocele. It has been reported that seeds of the plant possess antidiarroheal, antiviral, antibacterial, antimicrobial, antifungal, antidiabetic, antitumor, antipyretic and analgesic, antifilarial, anxiolytic, anti-inflammatory, antioxidant, immunomodulatory, adaptogenic, anticonvulsant, antispasmodic, nootropic, antifeedant, antiamoebic, antiestrogenic, diuretic, insecticidal as well as trypsin and chymotrypsin inhibitor properties [8-12]. Most of herbal medicines and their derivative products were often prepared from crude plant extracts, which comprise a complex mixture of different phytochemical constituents. The chemical features of these constituents differ considerably among different species. GCMS method used for the analysis of the obtained extracts can be an interesting tool for testing the amount of some active principles in herbs used in cosmetics, drugs, pharmaceutical or food industries.

Table 1: Taxonomy of Caesalpinia bonducella

\begin{tabular}{|c|c|}
\hline \multicolumn{2}{|c|}{ Scientific Classification } \\
\hline Kingdom & Plantae \\
\hline Phylum & Magnoliophyta \\
\hline Division & Angiospermae \\
\hline Class & Fabales \\
\hline Order & Fabaceae \\
\hline Family & Caesalpinia \\
\hline Genus & bonduc \\
\hline Species & Synonyms \\
\hline English Name & Fever nut, bonduc nut, nicker nut and nicker seed \\
\hline Tamil Name & Kalarci ver, Kalarcik Koluntu, Kalarcip paruppu, \\
& Kazharchikkaai, Kalichikai and Kazarci. \\
\hline Hindi Name & Kantkarej, Kantikaranja and Sagar Gota. \\
\hline Sanskrit Name & Kakachika, Kantakikaranja, Kuberaksi, Latakaranja, \\
& Prakirnah and Putikaranja \\
\hline Bengali Name & Nata \\
\hline Malayalam Name & Ban-karetti, Kaka-moullou, Kazhanji, Kalanci and \\
& Kajanchikkur \\
\hline Telugu Name & Mulluthige and Gaccakayai \\
\hline Kannada Name & Gajjiga, Kiri gejjuga and Gajikekayi \\
\hline
\end{tabular}




\section{MATERIALS AND METHODS}

Collection and Identification of

\section{Caesalpinia bonducella}

The leaves of Caesalpinia bonducella were collected from puthupalayam village, Villupuram District, Tamil Nadu, India. They were aunthenticated by Dr. N. Srinivasan., M.Pharm (Pharmacognosy), Assistant Professor, Department of Pharmacy, FEAT, Annamalai University, Annamalai Nagar, Chidambaram.

Extraction and Isolation of Drynaria Quercifolia

The leaves of Caesalpinia bonducella were dried under shade, segregated, pulverized by a mechanical grinder and passed through a 40 mesh sieve [13-15]. The powdered plant materials were stored in an air-tight container. The above powdered materials were successively extracted with ethanol by hot continuous percolation method in Soxhlet apparatus for 24 hours [16, 17]. The extract was concentrated by using a rotary evaporator $[18,19]$ and subjected to freeze drying in a lyophilizer [20] till dry powder was obtained.

\section{Gas Chromatography - Mass}

\section{Spectroscopy Analysis}

The Clarus $680 \mathrm{GC}$ was used in the analysis employed a fused silica column, packed with Elite-5MS (5\% biphenyl 95\% dimethylpolysiloxane, $30 \mathrm{~m} \times 0.25 \mathrm{~mm}$ ID $\times$ $250 \mu \mathrm{m} \mathrm{df})$ and the components were separated using Helium as carrier gas at a constant flow of $1 \mathrm{ml} / \mathrm{min}$. The injector temperature was set at $260^{\circ} \mathrm{C}$ during the chromatographic run. The $1 \mu \mathrm{L}$ of extract sample injected into the instrument the oven temperature was as follows: $60{ }^{\circ} \mathrm{C}(2 \mathrm{~min})$; followed by $300{ }^{\circ} \mathrm{C}$ at the rate of $10{ }^{\circ} \mathrm{C}$ $\min -1$; and $300{ }^{\circ} \mathrm{C}$, where it was held for 6 min. The mass detector conditions were: transfer line temperature $230{ }^{\circ} \mathrm{C}$; ion source temperature $230{ }^{\circ} \mathrm{C}$; and ionization mode electron impact at $70 \mathrm{eV}$, a scan time $0.2 \mathrm{sec}$ and scan interval of $0.1 \mathrm{sec}$. The fragments from 40 to $600 \mathrm{Da}$. The spectrums of the components [23] were compared with the database of spectrum of known components stored in the GC-MS NIST (2008) library (Table 2).

\section{Identification of phytocomponents}

Analysis on mass-spectrum GC-MS $[24,25]$ was conducted using the database of National Institute Standard and Technology (NIST) having more than 62,000 patterns. The spectrum of the unknown components was correlated with the spectrum of known components stored in the NIST library. The structure, name and molecular weight of the components of the test materials were confirmed. [26] 
Table 2: GC-MS Information

\begin{tabular}{|c|c|c|c|c|c|}
\hline \multicolumn{2}{|c|}{ Instrument information } & \multicolumn{2}{|c|}{ Acquisition parameters } & \multicolumn{2}{|c|}{ Mass condition (EI) } \\
\hline Make & Perkin Elmer & Oven & $\begin{array}{l}\text { Initial temp } 60^{\circ} \mathrm{C} \text { for } 2 \\
\text { min, ramp } 10^{\circ} \mathrm{C} / \mathrm{min} \text { to } \\
300^{\circ} \mathrm{C} \text {, hold } 6 \mathrm{~min},\end{array}$ & Solvent Delay & $2.00 \mathrm{~min}$ \\
\hline GC-model & clarus 680 & Total Run Time & $32.00 \mathrm{mins}$ & $\begin{array}{c}\text { Transfer } \\
\text { Temperature }\end{array}$ & $230^{\circ} \mathrm{C}$ \\
\hline $\begin{array}{c}\text { Mass } \\
\text { Spectrometer }\end{array}$ & clarus $600(\mathrm{EI})$ & $\begin{array}{c}\text { Inj.auto } \\
\text { Volume } \\
\text { Split }\end{array}$ & $\begin{array}{c}260^{\circ} \mathrm{C} \\
1 \mu \mathrm{L} \\
10: 1\end{array}$ & $\begin{array}{c}\text { Source } \\
\text { Temperature }\end{array}$ & $230^{\circ} \mathrm{C}$ \\
\hline Software & $\begin{array}{c}\text { TurboMassver } \\
5.4 .2 \\
\end{array}$ & $\begin{array}{l}\text { Flow Rate } \\
\text { Carrier Gas }\end{array}$ & 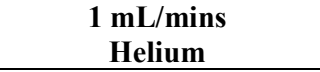 & Scan & $\begin{array}{l}50 \text { to } \\
600 D a\end{array}$ \\
\hline Library year & NIST-2008 & Column & $\begin{array}{c}\text { Elite-5MS (30.0m, } \\
0.25 \mathrm{mmID}, 250 \mu \mathrm{m} \text { df })\end{array}$ & & \\
\hline
\end{tabular}

\section{RESULTS AND DISCUSSION}

GC-MS analysis of ethanolic extract of leaves of Caesalpinia bonducella revealed various compounds with help of NIST library [27]. Totally 17 most abundant compounds with their retention time, molecular formula, molecular weight, peak area and applications were listed in Table 3 and GC-MS chromatogram of the seventeen peak of the compounds detected was shown in Figure 1.The ethanolic extract of seeds of Caesalpinia bonducella showed 17 bioactive compounds namely, Phytol, 2,3-Di-OMethyl-D-Xylopyranose, Alpha.-D-Mannofuranoside, 1-Nonyl --, Hexadecanoic acid, 1-(Hydroxymethyl) - 1,2-Ethanediyl ester, Undecanoic acid, Octadecanoic acid, Sulfurous acid, Octadecyl 2-Propyl ester, 11Eicosenoic acid, Trimethylsilyl ester, 2, 6,
10, 14, 18, 22-Tetracosahexaene, 2,6,10,15,19,23-Hexamethyl-, (All-E)-, Pregna-1,4-Diene-3， 20-Dione, 11，22Diacetoxy-16, 17-Propylidenedioxy-, 3 - (1Acetyl-2-OxoPropylsulfanyl) - 3, 3 Difluoro - 2 -Trifluoromethyl - Propionic acid methyl ester, 4, 4, 6A, 6B, 8A, 11, 11, 14B - Octamethyl 1, 4, 4A, 5,6, 6A, 6B,7,8, $8 \mathrm{~A}, 9,10,11,12,12 \mathrm{~A}, 14,14 \mathrm{~A}, 14 \mathrm{~B}$ Octadecahydro - 2, URS-12-EN-3-OL, Acetate,(3.BETA.)- and 2, 4, 4-Trimethyl 3-Hydroxymethyl - 5A- (3-Methyl-But-2Enyl) - Cyclohexene. The GC-MS of ethanolic extract of Caesalpinia bonducella shows a more number of active constituents. These active principles were used as various pharmacologic properties, cosmetic preparations and also used as a energy sources. 
Table 3: Phytocomponents identified in ethanolic extract of leaves of Caesalpinia bonducella

\begin{tabular}{|c|c|c|c|c|c|c|}
\hline S. No & RT & Compound Name & $\begin{array}{c}\text { Mol. } \\
\text { Formula }\end{array}$ & $\begin{array}{l}\text { Mol } \\
\text { Wt }\end{array}$ & $\begin{array}{l}\text { \%Peak } \\
\text { Area }\end{array}$ & Applications \\
\hline 1. & 17.309 & Phytol & $\mathrm{C}_{20} \mathrm{H}_{40} \mathrm{O}$ & 296 & 2.178 & $\begin{array}{c}\text { Commonly used as a precursor for the } \\
\text { manufacture of synthetic forms } \\
\text { of vitamin } E \text { and vitamin K1. Anti- } \\
\text { inflammatory, Antimicrobial, Anti- } \\
\text { inflammatory }\end{array}$ \\
\hline 4. & 18.395 & 2,3-Di-O-Methyl-D-Xylopyranose & $\mathrm{C}_{7} \mathrm{H}_{14} \mathrm{O}_{5}$ & 178 & 31.842 & Antioxidant \\
\hline 5. & 19.215 & Alpha.-D-Mannofuranoside, 1-Nonyl-- & $\mathrm{C}_{15} \mathrm{H}_{30} \mathrm{O}_{6}$ & 306 & 13.995 & Not reported \\
\hline 6. & 19.525 & $\begin{array}{c}\text { Hexadecanoic Acid, 1-(Hydroxymethyl)- } \\
\text { 1,2-Ethanediyl ester [28] }\end{array}$ & $\mathrm{C}_{35} \mathrm{H}_{68} \mathrm{O}_{5}$ & 568 & 15.403 & $\begin{array}{c}\text { Exhibits antioxidant, } \\
\text { hypocholesterolemic,antiandrogenic, } \\
\text { hemolytic and alpha reductase } \\
\text { inhibitor activity }\end{array}$ \\
\hline 7. & 20.375 & Undecanoic acid & $\mathrm{C}_{11} \mathrm{H}_{22} \mathrm{O}_{2}$ & 186 & 1.113 & $\begin{array}{c}\text { Antifungal agent, to treat ringworm } \\
\text { and athlete's foot }\end{array}$ \\
\hline 8. & 20.816 & Octadecanoic acid & $\mathrm{C}_{18} \mathrm{H}_{36} \mathrm{O}_{2}$ & 284 & 3.252 & $\begin{array}{l}\text { commonly used in the production of } \\
\text { detergents, soaps, and cosmetics, such } \\
\text { as shampoos and shaving cream } \\
\text { product and also used as an antifungal, } \\
\text { antitumor, and antibacterial }\end{array}$ \\
\hline 9. & 21.026 & Sulfurous acid, Octadecyl 2-Propyl ester & $\mathrm{C}_{21} \mathrm{H}_{44} \mathrm{O}_{3} \mathrm{~S}$ & 376 & 2.162 & Antibacterial \\
\hline 10. & 21.331 & 11-Eicosenoic acid, Trimethylsilyl ester & $\mathrm{C} 23 \mathrm{H} 46 \mathrm{O}_{2} \mathrm{Si}$ & 382 & 1.357 & $\begin{array}{c}\text { surfactant, emulsifier, nutrient, } \\
\text { membrane stabilizer, energy source } \\
\text { and storage. }\end{array}$ \\
\hline 11. & 23.747 & $\begin{array}{c}\text { 2,6,10,14,18,22-Tetracosahexaene, } \\
\text { 2,6,10,15,19,23-Hexamethyl-, (All-E)- }\end{array}$ & $\mathrm{C}_{30} \mathrm{H}_{50}$ & 410 & 3.894 & $\begin{array}{c}\text { Anticancer, antioxidant, drug carrier, } \\
\text { detoxifier, skin hydrating, and } \\
\text { emollient activities. }\end{array}$ \\
\hline 13. & 26.893 & $\begin{array}{l}\text { Pregna-1,4-Diene-3,20-Dione, 11,22- } \\
\text { Diacetoxy-16,17-Propylidenedioxy- }\end{array}$ & $\mathrm{C}_{28} \mathrm{H}_{36} \mathrm{O}_{8}$ & 500 & 1.223 & Not reported \\
\hline 14. & 27.068 & $\begin{array}{l}\text { 3-(1-Acetyl-2-Oxo-Propylsulfanyl)-3,3- } \\
\text { Difluoro-2-Trifluoromethyl-Propionic } \\
\text { acid Methyl ester }\end{array}$ & $\mathrm{C}_{10} \mathrm{H}_{11} \mathrm{O}_{4} \mathrm{~F}_{5} \mathrm{~S}$ & 322 & 4.035 & Not reported \\
\hline 15. & 27.348 & $\begin{array}{c}4,4,6 \mathrm{~A}, 6 \mathrm{~B}, 8 \mathrm{~A}, 11,11,14 \mathrm{~B}-\text { Octamethyl- } \\
\text { 1,4,4A,5,6,6A,6B,7,8,8A,9,10,11,12,12A,1 } \\
\text { 4,14A,14B-Octadecahydro-2 }\end{array}$ & $\mathrm{C}_{30} \mathrm{H}_{48} \mathrm{O}$ & 424 & 2.220 & Not reported \\
\hline 16. & 27.588 & URS-12-EN-3-OL, Acetate, (3.BETA.)- & $\mathrm{C}_{32} \mathrm{H}_{52} \mathrm{O}_{2}$ & 468 & 1.918 & Not reported \\
\hline 17. & 30.054 & $\begin{array}{l}\text { 2,4,4-Trimethyl-3-Hydroxymethyl-5A-(3- } \\
\text { Methyl-But-2-Enyl)-Cyclohexene }\end{array}$ & $\mathrm{C}_{15} \mathrm{H}_{26} \mathrm{O}_{2}$ & 222 & 0.817 & Antibacterial, Antioxidant [18] \\
\hline
\end{tabular}

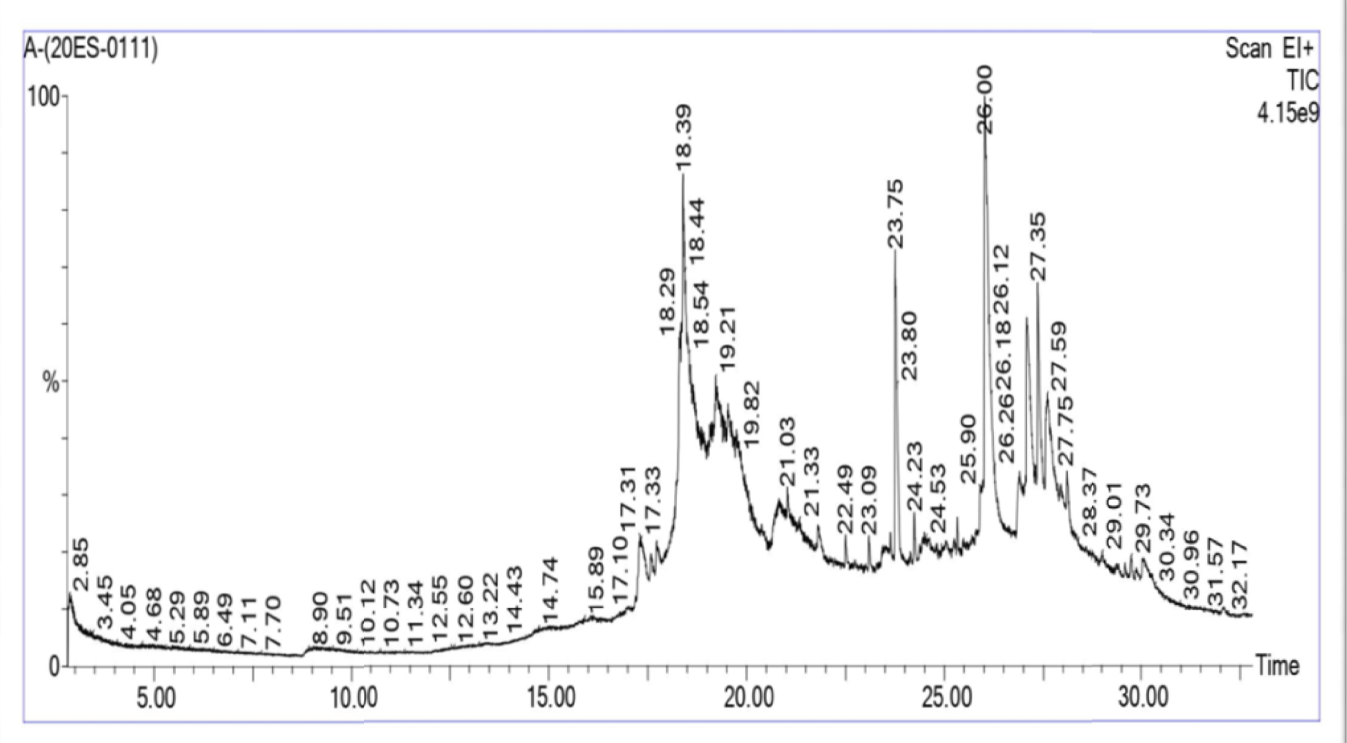

Figure 1: GC-MS Chromatogram of ethanolic extract of leaves of Caesalpinia bonducella

IJBPAS, June, 2020, 9(6) 


\section{CONCLUSION}

The GC-MS study on the leaves of Caesalpinia bonducella revealed the presence of various bio-active compounds. From this study it can be concluded that the Caesalpinia bonducella may serve as a new potential source of medicines due to the presence of these phytochemicals and bioactive compounds. These results further support the traditional use of this plant in medicine. This preliminary study gives an idea to isolate the major active constituents present in the plant and also helps to develop potential pharmacologically active compounds.

FINANCIAL SUPPORT

None.

\section{CONFLICT OF INTEREST}

All authors declare that there is no conflict of interest.

\section{AUTHORS' CONTRIBUTIONS}

All the authors contributed equally to the paper.

\section{REFERENCES}

[1] Asolkar LV, Kakkar KK, Chakre OJ, Second Suppl. Part 1, To glossary of Indian medicinal plants with active principles, 1992, New Delhi: PIDCSIR, 150

[2] Nazeerullah K, Sunil K, Pal SR, Neelam D, A Pharmacognostic and pharmacological overview on Caesal pinia bonducella, Res J Pharma, Biol and Chem Sci, 3, 2012, 480-496.

[3] Moon K, Khadabadi SS, Deokate UA, Deore SL, Caesalpinia bonducella F- An overview, Report and Opinion, 2, 2010, 83-90.

[4] S. Sivakrishnan and J.Kavitha, Herbal Drugs, Diet and Lifestyle Changes for Liver Diseases- A Review, Journal of Global Pharma Technology, 11(03), 2019, 12-21.

[5] M. Swamivelmanickam and S. Sivakrishnan, Ethnopharmacology of Boraginaceae Family- An Update, Journal of Global pharma Technology, 11 (9), 2019, 10-24.

[6] S. Sivakrishnan and M Swamivelmanickam, A comprehensive review of hepatotoxins, International Research Journal of Pharmacy, 6(10), 2019, 1-4.

[7] Sivakrishnan $S$ and Swamivelmanickam M, A comprehensive review of Albizia procera (Roxb.) Benth.-An update, Int J Pharm Sci \& Res, 10(9), 2019, 4129-4144.

[8] Kshirsagar Sunil N, Nootropic activity of dried seed kernels of Caesalpinia crista Linn against scopolamine induced amnesia in 
mice, Int J Pharma Tech Res, 3, 2011, 104-109.

[9] Emmanuel N, Swaran D, Biological effects of Caesalpinia crista seed extracts on Helicover paarmigera (Lepidoptera: Noctuidae) and its predator, Coccinella septumounctete (Coleoptera: Coccinellidae), J AsiaPacific Entomol. 9, 2006, 159-164.

[10] Raghunathan K, Mitra R, Pharmacognosy of indigenous drugs, part-I. Edited by: Raghunathan K, Mitra R, New Delhi: Central Council for Research in Ayurveda Siddha, I982, 484-510.

[11] Khedkar A, Mandavkar YD, Shinde G, Khalure P, Pravin D, Diuretic effect of Caesalpinia bonduc in rats, Bangladesh J Pharmacol, 6, 2011, 61-63.

[12] Arindam B, Shruti R, Babu CR, A trypsin and chymotrypsin inhibitor from Caesalpinia bonduc seeds: Isolation, partial characterization and insecticidal properties, Plant Physiol and Biochem, 45, 2007, 169-177.

[13] Sivakrishnan S and Kottaimuthu A, Phytochemical Evaluation of Ethanolic Extract of Aerial Parts of
Albizia procera, Brtitish Biomedical Bulletin, 2(1), 2014, 235-241.

[14] S. Sivakrishnan and A. Kottai Muthu, In Vitro free radical scavenging activity of aerial parts of ethanolic extract of Albizia procera (Family: Mimosoideae), Int. $\mathrm{J}$ of Pharm. and Pharmaceu. Sci., 5(3), 2013, 352-354.

[15] S.Sivakrishnan, J.Kavitha and A. Kottai Muthu, Antioxidant potential, total phenolic and flavonoids content of aerial parts of ethanolic extract of Albizia procera (Family: Mimosoideae), Asian Journal of pharmaceutical and Clinical Research, 6(1), 2013,108-110.

[16] S.Sivakrishnan and A.KottaiMuthu, In vivo Antioxidant Activity of ethanolic extract of aerial parts of Albizia procera roxb (benth.) against paracetamol induced liver toxicity on wistar rats, Journal of Pharmaceutical Science and Research, 5(9), 2013, $174-177$.

[17] S.Sivakrishnan and G.Veeramani, Phytochemical activity of aerial parts of Cordia obliqua Willd, Int. Res. J. Pharm, 10(7), 2019, 94-98.

[18] M. Swamivelmanickam and S. Sivakrishnan, Antioxidant Potential, 
Total Phenolic and Flavonoids Content of Aerial Parts of Ethanolic Extract of Cordia Obliqua, Journal of Global Pharma Technology, 11(8), 2019, 5-7.

[19] G.Veeramani, S.Sivakrishnan and A.Kottaimuthu, Isolation of Active Compounds from Aerial Parts of Albizia procera, Journal of Global pharma Technology, 11(3), 2019,16.

[20] A. Kottaimuthu and S.Sivakrishnan, Evaluation of hepatoprotective activity of squalene isolated from Albizia procera against paracetamol induced hepatotoxicity on wistar rats, World journal of pharmacy and pharmaceutical sciences, 3(3), 2014, 1351-1362.

[21] Sivakrishnan S, Kottaimuthu A and Kavitha J, GC-MS analysis of ethanolic extract of aerial parts of Albizia procera (Roxb.) Benth, Int. J. Pharmacy and Pharm. Sciences, 5, 2013, 702-704.

[22] Sivakrishnan S and Pradeepraj D, "Gas chromatography - mass spectroscopy analysis of ethanolic extract of leaves of cordia obliqua willd", Asian Journal of
Pharmaceutical and Clinical Research, 12(6), 2019, 110-112.

[23] Ronald Hites A, Gas Chromatography Mass Spectroscopy: Handbook of Instrumental Techniques for Analytical Chemistry, 1997, 609611.

[24] Jayapriya G, Gricilda Shoba F, GCMS analysis of bioactive compounds in methanolic leaf extracts of justicia adhatoda Linn, Journal of Pharmacognosy and Phytochemistry, 4(1), 2015,1131176.

[25] Kanthal LK, Dey A., Satyavathi, K., Bhojaraju, GC-MS analysis of bioactive compounds in methanolic extract of lactuca runcinata DC, Pharmacognosy Res, 6(1), 2015, 58-61.

[26] Ezhilan BP, Neelamegam R, GCMS analysis of phytocomponents in the ethanol extract of Polygonum chinense L, Phcog Res, 4(1), 2012, 4-11.

[27] Mass Spectrometry Data Centre, Eight peak index of mass spectra: The eight most abundant ions in 31,101 mass spectra, indexed by molecular weight, elemental 
composition and most abundant ion (4 volume set). $2^{\text {nd }}$ edition, Alder maston: Mass Spectrometry Data Centre, 1974.

[28] B Perumal Ezhilan and Ramasamy Neelamegam, GC-MS analysis of phytocomponents in the ethanol extract of Polygonum chinense L, Pharmacognosy Res, 4(1), 2012, 11-14.
[29] Sunita Arora and Ganesh Kumar, Gas Chromatography - Mass Spectrometry (GC - MS) determination of bioactive constituents from the methanolic and ethyl acetate extract of Cenchrus setigerus Vahl (Poaceae), The Pharma Innovation Journal, 6(11), 2017, 635-640. 